\title{
Anaerobic Soil Disinfestation Reduces Germination and Affects Colonization of Sclerotium rolfsii Sclerotia
}

\author{
Utsala Shrestha, Mary E. Dee, Bonnie H. Ownley, and David M. Butler ${ }^{\dagger}$
}

First and fourth authors: Department of Plant Sciences, and second and third authors: Department of Entomology and Plant Pathology, University of Tennessee, Knoxville.

Accepted for publication 15 October 2017.

\begin{abstract}
Growth chamber and field studies were conducted with organic amendment mixtures of carbon $(\mathrm{C})$ and nitrogen $(\mathrm{N})$ at $\mathrm{C}: \mathrm{N}$ ratios 10:1, 20:1, 30:1, and 40:1 and amendment rates of $C$ at $2,4,6$, and $8 \mathrm{mg} / \mathrm{g}$ of soil (C:N ratio 30:1) to evaluate anaerobic soil disinfestation (ASD) effects on germination and colonization of Sclerotium rolfsii. In the growth chamber, sclerotial germination was reduced in all ASD treatments regardless of $\mathrm{C}: \mathrm{N}$ ratio $(0.6$ to $8.5 \%$ germination) or amendment rate $(7.5$ to $46 \%$ ) as compared with nonamended controls ( 21 to $36 \%$ and 61 to 96\%, respectively). ASD treatment increased Trichoderma spp. colonization of sclerotia, with consistently higher colonization in ASD treatments

with amendment rates of $\mathrm{C}$ at 2 or $4 \mathrm{mg} / \mathrm{g}$ of soil ( $>87 \%$ colonization) compared with nonamended controls $(<50 \%$ colonization). In the 2014 field study, sclerotial germination was reduced by 24 to $30 \%$ in ASD treatments when compared with the nonamended control. Sclerotial colonization by Trichoderma spp. was predominant; however, other potential mycoparasites (i.e., Aspergillus spp., Fusarium spp., zygomycetes, and other fungi) were present in the field study. Amendment C:N ratios in the range of 10:1 to 40:1 were equally effective in reducing sclerotial germination and enhancing colonization by potentially beneficial mycoparasites of sclerotia.
\end{abstract}

With the mandated phase-out of the ozone-depleting fumigant methyl bromide $(\mathrm{MeBr})$, vegetable and small fruit growers need alternative methods to control soilborne plant pathogens. This has led to the introduction of several alternative fumigants for these high-value crops. However, these alternative methods do not control all pathogens and pests targeted by $\mathrm{MeBr}$ (Belova et al. 2013) and all soil fumigants face regulatory restrictions to protect human health (Csinos et al. 2002; Martin 2003). In this scenario, anaerobic soil disinfestation (ASD) has potential as a nonchemical alternative to soil fumigants (Butler et al. 2012b; Rosskopf et al. 2015; Shennan et al. 2014). Initiated in Japan and the Netherlands in the 2000s, ASD has evolved as an effective measure to control soilborne pathogens and nematodes (Shrestha et al. 2016). Significant decreases in disease were observed with initial ASD studies (Blok et al. 2000; Momma et al. 2006). Application of organic amendments to soil to suppress disease has been widely studied also (Bonanomi et al. 2010, 2013). ASD emphasizes using readily available organic amendments as a source of labile carbon (C) in saturated and covered soil to create anaerobic conditions, enhance populations of microbial biocontrol agents, and release decomposition byproducts (volatile fatty acids and other compounds) to suppress soilborne pathogens (Hewavitharana et al. 2014; Rosskopf et al. 2015), suggesting that the rate of added $\mathrm{C}$ is a key determinant of ASD treatment efficacy. Anaerobic conditions are achieved by filling soil pore space with water, reducing air exchange to the atmosphere by tarping, and microbial respiration of available soil oxygen during decomposition of the added organic amendment. Thus far, ASD effectiveness has been most well documented against soilborne fungal pathogens, although there are also a limited number of studies on oomycetes and bacterial pathogens (Shrestha et al. 2016).

†Corresponding author: D. M. Butler; E-mail: dbutler@utk.edu

Funding support for this research was provided by the National Institute of Food and Agriculture, U.S. Department of Agriculture, under award number 201251102-20293 (Methyl Bromide Transitions Program).

(c) 2018 The American Phytopathological Society
Sclerotium rolfsii Sacc. (current name: Athelia rolfsii (Curzi) C. C. Tu \& Kimbr.) is a sclerotia-forming, necrotrophic soilborne pathogen known to cause seedling damping-off, root rot, and stem rot. The disease is commonly called southern blight. $S$. rolfsii is economically important because it infects more than 500 plant species. In the United States, $S$. rolfsii is reported mainly in the southern region with tropical, subtropical, and warm temperate climates (Punja 1985; Xu et al. 2009). S. rolfsii is also an active saprophyte, surviving several years (Aycock 1966; Coley-Smith and Cooke 1971) in a wide range of soil temperature and soil $\mathrm{pH}$ (Coley-Smith et al. 1974).

A comprehensive meta-analysis showed that use of various types of amendments with ASD reduces viability of many sclerotial pathogens, including $S$. rolfsii (Shrestha et al. 2016). Amendments, including agricultural byproducts, cereal brans, crop residues, and animal manures, were incorporated in soil to test ASD effectiveness on suppression of sclerotia or microsclerotia (Rosskopf et al. 2015; Strauss and Kluepfel 2015) of Verticillium dahliae (Blok et al. 2000; Goud et al. 2004; Shennan et al. 2007; Thaning and Gerhardson 2001), Macrophomina phaseolina (Rosskopf et al. 2010, 2014), and Rhizoctonia solani (Blok et al. 2000; Hewavitharana and Mazzola 2013; McCarty et al. 2014). All of these pathogens were well suppressed by ASD treatment. Only a few studies on ASD techniques have been conducted in controlled environments (i.e., growth chamber and greenhouse studies) to observe impacts on S. rolfsii; with warm-season cover crops in Florida (Butler et al. 2012b) and cool-season cover crops in Tennessee (McCarty 2012). Reduction in sclerotial germination was reported in Florida trials with liquid molasses; however, the result was inconsistent between trials (Butler et al. 2012b). Similarly, in Tennessee trials, only cereal rye as a carbon amendment resulted in a consistent reduction in sclerotial germination in both trials, indicating that type of $\mathrm{C}$ amendment may have an effect on sclerotial survival and germination (McCarty 2012). Soil amendments play a critical role in determining microbial population structure (Fernandez et al. 2016; Reardon and Wuest 2016; Tao et al. 2015), decomposition rates (Akhtar and Malik 2000), plant growth (Rodríguez-Kábana et al. 1987), and, collectively, the effectiveness of ASD (Butler et al. 
$2012 b)$. Thus, it is imperative to identify the properties and rates of $\mathrm{C}$ amendment that are needed to suppress germination of S. rolfsii.

The ratio of $\mathrm{C}$ to nitrogen $(\mathrm{N})(\mathrm{C}: \mathrm{N})$ in organic soil amendments is known to be important for shifts in microbial population structure and decomposition of organic matter (Leite et al. 2017). At the same time, both high $\mathrm{C}: \mathrm{N}$ ratio amendments (e.g., ethanol, glucose, and molasses) and low to moderate $\mathrm{C}: \mathrm{N}$ ratio amendments (cover crop residue, grape pomace, wheat bran, and rice bran) have been successfully used as ASD amendments (Shennan et al. 2014). Physiologically, soil microbial biomass stoichiometry is fairly constrained within a $\mathrm{C}: \mathrm{N}$ ratio range of approximately $5: 1$ to $7: 1$ (Spohn 2015), with a threshold for $\mathrm{N}$ limitation on growth at approximately 20:1 to 25:1 (Sinsabaugh et al. 2013). Accordingly, C use efficiency and soil microbial decomposition of amendments at relatively high $\mathrm{C}: \mathrm{N}$ ratios (i.e., low $\mathrm{N}$ concentration) is reduced due to $\mathrm{N}$ limitation. Although aerobic microbial communities may "dispose" of excess C through increased respiration or metabolic activity and release of dissolved organic $\mathrm{C}$ compounds (Hessen and Anderson 2008; Spohn 2015), anaerobic microbes are metabolically constrained by reduction-oxidation reactions. However, certain anaerobic microbes are known to change fermentation pathways due to changes in substrate availability and nutrient limitation, resulting in differing profiles of anaerobic decomposition byproducts (Streekstra et al. 1987; Thomas et al. 1979) which, in the case of ASD treatment, could alter treatment mechanisms and efficacy in given pathosystems.

In this study, the efficacy of ASD using organic amendments of $\mathrm{C}$ at rates of 2, 4, 6, and $8 \mathrm{mg} / \mathrm{g}$ of soil (constant C:N ratio of 30:1) and C:N ratios of 10:1, 20:1, 30:1, and 40:1 (constant $C$ rate of $4 \mathrm{mg} / \mathrm{g}$ of soil) was evaluated for germination suppression of sclerotia of $S$. rolfsii. The specific aims were to (i) evaluate cumulative redox potential of soils treated with $\mathrm{C}$ amendments at a range of $\mathrm{C}$ rates and $\mathrm{C}: \mathrm{N}$ ratios for ASD treatment, (ii) examine germination and colonization of introduced sclerotia of $S$. rolfsii using ASD amendment mixtures at a range of $\mathrm{C}: \mathrm{N}$ ratios (10:1 to 40:1) in growth chamber and field conditions, and (iii) examine germination and colonization of introduced sclerotia of $S$. rolfsii using ASD amendments of $\mathrm{C}$ at rates from 2 to $8 \mathrm{mg} / \mathrm{g}$ of soil in growth-chamber conditions.

\section{MATERIALS AND METHODS}

Sclerotia production and inoculum preparation. $S$. rolfsii was isolated from hybrid field tomato crops grown at the University of Tennessee (UT) Organic Crops Unit, East Tennessee Research and Education Center, Knoxville. S. rolfsii was cultured on potato dextrose agar (PDA) for 7 days, and plugs were transferred to the center of freshly prepared PDA plates. Cultures were incubated at room temperature. After 4 to 6 weeks, mature sclerotia of consistent large size and dark color were harvested, dried overnight under a laminar flow hood, and stored in sterile glass vials until use in the experiment. Ten sclerotia were sealed in each 5-by-5-cm permeable packet (aperture Delnet polyolefin fabric; DelStar Technologies, Austin, TX) and string was attached for easy retrieval of the packet from soil. Although the use of culture-produced sclerotia rather than sclerotia formed on soil has been debated in the literature (Punja
1985), the consistency of culture-produced sclerotia and lack of microbial contamination was deemed important to study objectives. Although some physiological and morphological differences have been reported among sclerotia production methods (Linderman and Gilbert 1973; Punja et al. 1984), it is unclear as to how sclerotia production methods affect survivability, germination, and colonization during soil disinfestation methods in field conditions, and the results of the present study should be interpreted in that context.

Growth chamber or pot trials 1 and 2: ASD amendment type and $\mathrm{C}: \mathrm{N}$ ratio effect. A Dewey silt loam (fine, kaolinitic, thermic, Typic Paleudult) was collected from a field at the UT Organic Crops Unit, sieved through a 10-mm aluminum mesh, and mixed with fine sand $(1: 1[\mathrm{vol} / \mathrm{vol}])$. The soil and sand mixture was placed in tall black plastic pots $\left(12 \mathrm{~cm}\right.$ in diameter, $23 \mathrm{~cm}$ in height, $2,500 \mathrm{~cm}^{3}$ in volume) with two pathogen packets placed at 5- and $15-\mathrm{cm}$ depths. Initial total soil $\mathrm{C}$ content was $10 \mathrm{~g} / \mathrm{kg}$ of soil, with a soil C:N ratio of 11.9. Soil treatments consisted of two main treatments: (i) dry molassesbased mixture and (ii) wheat bran-based mixture at four C:N ratios: 10:1, 20:1, 30:1, and 40:1 (Tables 1 and 2). Control pots without amendments were included for each main treatment. All pots were saturated with tap water to replace air-filled pore space with water. Pots were irrigated and then covered with standard mulch polyethylene, which was secured to the pot with a heavy-duty rubber band. No further irrigation was applied during treatment. Pots were randomly positioned on a wire rack in an environmental growth chamber (TC2 Controller; ECG, Chagrin Falls, $\mathrm{OH})$ with temperature at 25 and $15^{\circ} \mathrm{C}$ day and night, respectively, to approximate environmental conditions typical during spring soil treatment in warm temperate to subtropical climates (McCarty et al. 2014). The study was a completely randomized design with four replications. Trials were conducted on 30 April 2013 (trial 1) and repeated on 22 May 2013 (trial 2).

Growth chamber and pot trials 3 and 4: ASD amendment rate effect. To determine the effect of ASD amendment rates on sclerotial germination and colonization by potential microbial antagonists, growth chamber experiments were initiated on 17 June 2014 (trial 3) and 29 May 2015 (trial 4), as described for growth chamber pot study trials 1 and 2 . Initial soil C content was $5.5 \mathrm{~g} / \mathrm{kg}$ of soil, with a soil C:N ratio of 12.8. Treatments included ASD amendment rates of $\mathrm{C}$ at $2,4,6$, and $8 \mathrm{mg} / \mathrm{g}$ of soil, created by mixing dry molasses with corn starch at a C:N ratio of 30:1 (Tables 1 and 2). Two nonamended control treatments, one with and one without polyethylene mulch, were included. The control without polyethylene mulch was irrigated initially as other treatments with polyethylene mulch. The design was completely randomized, with four replications.

Field study. A field study was established at the UT Plateau Research and Education Center in Crossville on 16 May 2013 and 13 May 2014. Four ASD treatments were established at four amendment $\mathrm{C}: \mathrm{N}$ ratios $(10: 1,20: 1,30: 1$, and 40:1), at a total amendment rate of $\mathrm{C}$ at $4 \mathrm{mg} / \mathrm{g}$ of soil, with dry molasses-based mixtures used as the ASD amendment (Tables 1 and 2). In addition, an amendment $\mathrm{C}: \mathrm{N}$ ratio of $30: 1$, at a lower rate of $\mathrm{C}$ at $2 \mathrm{mg} / \mathrm{g}$ of soil, and a nonamended untreated control were included. Amendment rates were calculated based on soil mass calculated for the 0-to-20-cm horizon based on measured soil bulk density. Research was conducted in different sites of the same field in each

TABLE 1. Anaerobic soil disinfestation amendment properties

\begin{tabular}{|c|c|c|c|c|c|c|c|c|c|c|c|c|}
\hline \multirow[b]{2}{*}{ Soil amendment } & \multirow[b]{2}{*}{ Particle size $(\mathrm{mm})$} & \multirow[b]{2}{*}{$\mathrm{pH}$} & \multirow[b]{2}{*}{ Moisture $(\%)^{\mathrm{x}}$} & \multirow[b]{2}{*}{$\mathrm{N}(\%)^{\mathrm{y}}$} & \multirow[b]{2}{*}{$\mathrm{C}(\%)$} & \multirow[b]{2}{*}{$\mathrm{C}: \mathrm{N}$} & \multicolumn{6}{|c|}{ Mineral content (g/kg) } \\
\hline & & & & & & & $\mathrm{DO} \mathrm{Cz}$ & $\mathrm{Ca}$ & $\mathrm{K}$ & $\mathrm{Mg}$ & $\mathrm{P}$ & $\mathrm{S}$ \\
\hline Dry molasses & $0.2-4.5$ & 6.5 & 0.06 & 1.3 & 38.7 & 29.7 & 10.6 & 8.8 & 40.3 & 4.6 & 0.9 & 7.4 \\
\hline Soybean meal & $0.15-5$ & 7.4 & 0.08 & 8.8 & 42.6 & 4.8 & 4.8 & 4.5 & 22.2 & 3.7 & 7.0 & 4.1 \\
\hline Wheat bran & $0.2-4.5$ & 7.3 & 0.05 & 3.1 & 40.3 & 13.3 & 2.9 & 1.0 & 12.5 & 6.4 & 12.5 & 1.8 \\
\hline Corn starch & $<0.03$ & 5.5 & 0.15 & 0.0 & 41.7 & N/A & 0.1 & 0.1 & 0.2 & 0.1 & 0.2 & 0.2 \\
\hline
\end{tabular}

$\mathrm{x}$ Gravimetric moisture content.

y Elemental content presented on dry matter basis.

${ }^{z}$ Dissolved organic (DO) C, hot and cold water extractable. 
year. In 2013, the initial gravimetric soil moisture content was 2.5 to $2.7 \mathrm{~g} / \mathrm{g}$ of soil, total C content was $11 \mathrm{~g} / \mathrm{kg}$ of soil, and soil C: $\mathrm{N}$ ratio was 12.9. In 2014, the initial gravimetric soil moisture content was 2.7 to $3.1 \mathrm{~g} / \mathrm{g}$ of soil, C content was $12 \mathrm{~g} / \mathrm{kg}$ of soil, and soil C: $\mathrm{N}$ ratio was 13.4. The experiment was a randomized complete block design with four replications. Each plot was 7.6 by $1.8 \mathrm{~m}$. The soil type was a Lily series (fine-loamy, siliceous, semiactive, mesic Typic Hapludult). Amendments were applied in each plot using a drop fertilizer spreader and were thoroughly incorporated in soil with a rotovator to approximately $20 \mathrm{~cm}$ in depth. Raised beds (approximately $5 \mathrm{~cm}$ ) were formed and mulched with standard black polyethylene. Two packets of sclerotia were inserted in soil at a depth of $10 \mathrm{~cm}$ in the field to assess the effect of ASD on sclerotial germination and colonization by potential microbial antagonists. Beds were irrigated with $5 \mathrm{~cm}$ of water at the initiation of ASD treatment based on the amount of water needed to saturate soil to a depth of approximately $20 \mathrm{~cm}$. Irrigation was applied for $9.3 \mathrm{~h}$ using a single drip irrigation line installed in the center of each bed under the polyethylene mulch.

Assessment of sclerotia following ASD treatment. After ASD treatment ( 3 weeks), packets were collected from the pots in growth chamber studies and fields and stored in sealed bags at $4^{\circ} \mathrm{C}$ until examined. Packets containing sclerotia were washed with tap water to remove adhering soil, sonicated for $1 \mathrm{~min}$, and surface sterilized in $10 \%$ commercial bleach for $1 \mathrm{~min}$ followed by $1 \mathrm{~min}$ in $10 \%$ ethanol. Sclerotia were carefully removed from packets, plated onto PDA amended with fenpropathrin at $6.9 \mathrm{mg} /$ liter (Danitol 2.4 EC; Valent Chemical, Walnut Creek, CA) and rifampicin at $10 \mathrm{mg} /$ liter (Sigma-Aldrich, St. Louis), and incubated at room temperature for 4 to 6 weeks. Sclerotia that were soft at plating and failed to germinate were recorded as decomposed. Germination of sclerotia was confirmed by mycelial growth at 3 to 5 days. Production of new sclerotia and colonization by Trichoderma spp. and other microbial antagonists were observed and identified over a 4- to 6-week period.

Soil moisture, temperature, $\mathrm{pH}$, and anaerobic conditions. Each pot in the growth chamber study was equipped with an oxidation-reduction electrode (Combination ORP Electrode; Sensorex Corp., Garden Grove, CA) at a $15-\mathrm{cm}$ depth to measure cumulative redox potential. The temperature and volumetric moisture content (only for trials 3 and 4 ) of the soil mixture of each representative treated pot (two replicates) were recorded using temperature-moisture sensors at $10 \mathrm{~cm}$ (5TM Soil Moisture Probe; Decagon Devices, Pullman, WA). Soil samples from each pot were collected from depths of 0 to $10 \mathrm{~cm}$ at ASD termination using a clean plastic spoon and composited for gravimetric soil moisture content; then, air-dried soil was used to determine soil $\mathrm{pH}$, which was completed with a $2: 1$ ratio of $0.01 \mathrm{M} \mathrm{CaCl}_{2} / \mathrm{soil}$, and $\mathrm{pH}$ was determined with a $\mathrm{pH}$ electrode (Orion 3-Star Plus $\mathrm{pH}$ Benchtop Meter; Thermo Scientific, Waltham, MA). The soil $\mathrm{pH}$ values in $\mathrm{CaCl}_{2}$ were adjusted to soil $\mathrm{pH}$ in water by adding $0.6 \mathrm{U}$ to approximate equivalent values of soil $\mathrm{pH}$ determined in soil and deionized water suspension while reducing measurement interference due to varying soil electrolyte concentrations (Kissel et al. 2009). The cumulative anaerobic conditions of soil over a 3-week treatment period was calculated as described by Butler et al. (2012a). In field trials, anaerobic condition was determined by an iron-oxyhydroxidecoated indicator of reduction in soils (IRIS) tubes (Castenson and Rabenhorst 2006). Tubes were inserted in each plot at depths of 5 to $15 \mathrm{~cm}$ before irrigation and retrieved after the 3-week treatment and cleaned with tap water, and removal of paint was assessed as described by Rabenhorst (2012). Ten soil cores from depths of 0 to $15 \mathrm{~cm}$ were collected from each plot and combined for determination of soil moisture and soil $\mathrm{pH}$.

Statistical analysis. Data were analyzed with mixed model analysis of variance using SAS 9.4 (SAS Institute, Cary, NC) and differences between means were determined with Tukey's test $(P<$ $0.05)$. In repeated trials in the pot study, ASD amendment type and ASD amendment $\mathrm{C}: \mathrm{N}$ ratio effects were analyzed separately as completely randomized factorial analysis designs, where ASD amendments, amendment $\mathrm{C}: \mathrm{N}$ ratios, and depth were treated as fixed factors. The amendment $\mathrm{C}$ rate study was analyzed as a completely randomized design, with amendment $\mathrm{C}$ rate as a fixed effect. Burial depth data were pooled because the results from repeated trials were consistent, with no significant interactions between depth and amendment $\mathrm{C}$ rate effect. Field studies were analyzed separately each year. Within field experiments, ASD amendment $\mathrm{C}: \mathrm{N}$ ratio was treated as a fixed effect and replication as a random effect. For all studies, data were checked for outliers before analysis, and nonnormal and unequal variances were transformed using arcsine square root or rank transformations as appropriate. Nontransformed means and standard error of the mean are

TABLE 2. Anaerobic soil disinfestation treatment carbon to nitrogen $(\mathrm{C}: \mathrm{N})$ ratios, amendment types, and amendment rates in pot trials 1 and 2 (amendment and C:N ratio study), pot trials 3 and 4 (C rate study), and field trials (C:N ratio study)



y Primary amendment adjusted with corn starch (CS) or soybean meal (SM).

${ }^{\mathrm{z}} \mathrm{LC}=$ low carbon. 
reported. Relationships between soil moisture, cumulative anaerobic conditions, and rates of germination and colonization of sclerotia were assessed with correlation analysis at $P<0.05$. Pearson $(r)$ or Spearman $\left(r_{s}\right)$ correlation coefficients are reported when the correlation was significant.

TABLE 3. Effect of anaerobic soil disinfestation (ASD) amendment on mean posttreatment gravimetric soil moisture, posttreatment soil $\mathrm{pH}$, and anaerobic conditions from pot trials 1 and 2 (amendment and $\mathrm{C}: \mathrm{N}$ ratio study $)^{\mathrm{y}}$

\begin{tabular}{lllc}
\hline & $\begin{array}{c}\text { Gravimetric } \\
\text { soil moisture } \\
(\mathrm{g} / \mathrm{g})\end{array}$ & Soil $\mathrm{pH}$ (units) & $\begin{array}{c}\text { Soil anaerobic } \\
\text { condition } \\
(\mathrm{V} \mathrm{h})\end{array}$ \\
\hline Trial, amendment ${ }^{\mathrm{z}}$ & & & \\
\hline 1 Control & $0.22 \pm 0.0$ & $6.0 \pm 0.0$ & $42.7 \pm 15.3 \mathrm{~b}$ \\
$\quad$ Dry molasses based & $0.22 \pm 0.0$ & $5.9 \pm 0.1$ & $185.3 \pm 10.6 \mathrm{a}$ \\
Wheat bran based & $0.22 \pm 0.0$ & $5.8 \pm 0.1$ & $157.6 \pm 12.8 \mathrm{a}$ \\
$P$ value & 0.607 & 0.492 & $<0.0001$ \\
& & & \\
Control & $0.24 \pm 0.0 \mathrm{~b}$ & $5.3 \pm 0.0$ & $82.3 \pm 20.3 \mathrm{~b}$ \\
Dry molasses based & $0.27 \pm 0.0 \mathrm{a}$ & $5.4 \pm 0.1$ & $196.0 \pm 10.4 \mathrm{a}$ \\
$\quad$ Wheat bran based & $0.26 \pm 0.0 \mathrm{a}$ & $5.3 \pm 0.1$ & $165.2 \pm 10.0 \mathrm{a}$ \\
$P$ value & 0.003 & 0.188 & $<0.0001$ \\
\hline
\end{tabular}

y For each trial, within a column, values $=$ least square means \pm standard error of four replicate pots. Values followed by different letters are significantly different according to Tukey's test at $P<0.05$.

${ }^{\mathrm{z}}$ Control $=$ covered, nonamended control.

\section{RESULTS}

ASD amendment C:N ratio effect on anaerobic conditions, and germination and colonization of sclerotia in pot trials 1 and 2. A significant but moderate negative correlation between sclerotial germination and cumulative anaerobic conditions $\left(r_{s}=-0.4\right.$, $P<0.01)$ was observed in trial 1 . No relationship between sclerotial germination and cumulative anaerobic conditions was observed in trial 2 , with a correlation value of $0.27(P=0.09)$. No interactions among ASD amendment type, ASD amendment C:N ratio, or soil depth were observed for sclerotial germination, decomposition, or colonization in either trial.

Mean soil temperatures did not differ across treatments and ranged from 28.4 to $29.4^{\circ} \mathrm{C}$ during the day and 18.4 to $19.3^{\circ} \mathrm{C}$ during the night. The volumetric water content of soil was higher in nonamended control treatments and lowest in treatments amended with wheat bran (data not shown). In contrast, gravimetric soil moisture content was slightly lower in the control than in ASD treatments in trial 2, possibly due to the moisture-holding capacity of added organic amendments (Table 3). Gravimetric soil moisture content was lower in trial 1 than trial 2. Soil $\mathrm{pH}$ was measured after ASD treatment and did not differ across ASD amendment type but differed among ASD amendment $\mathrm{C}: \mathrm{N}$ ratios. The lowest soil $\mathrm{pH}$ was recorded in ASD-treated pots with an amendment $\mathrm{C}: \mathrm{N}$ ratio of 10:1 (4.9 and 5.3, trial 1 and trial 2, respectively) (Fig. 1A). An interaction between ASD amendment type and ASD amendment $\mathrm{C}: \mathrm{N}$ ratio was observed for soil $\mathrm{pH}$ but was only
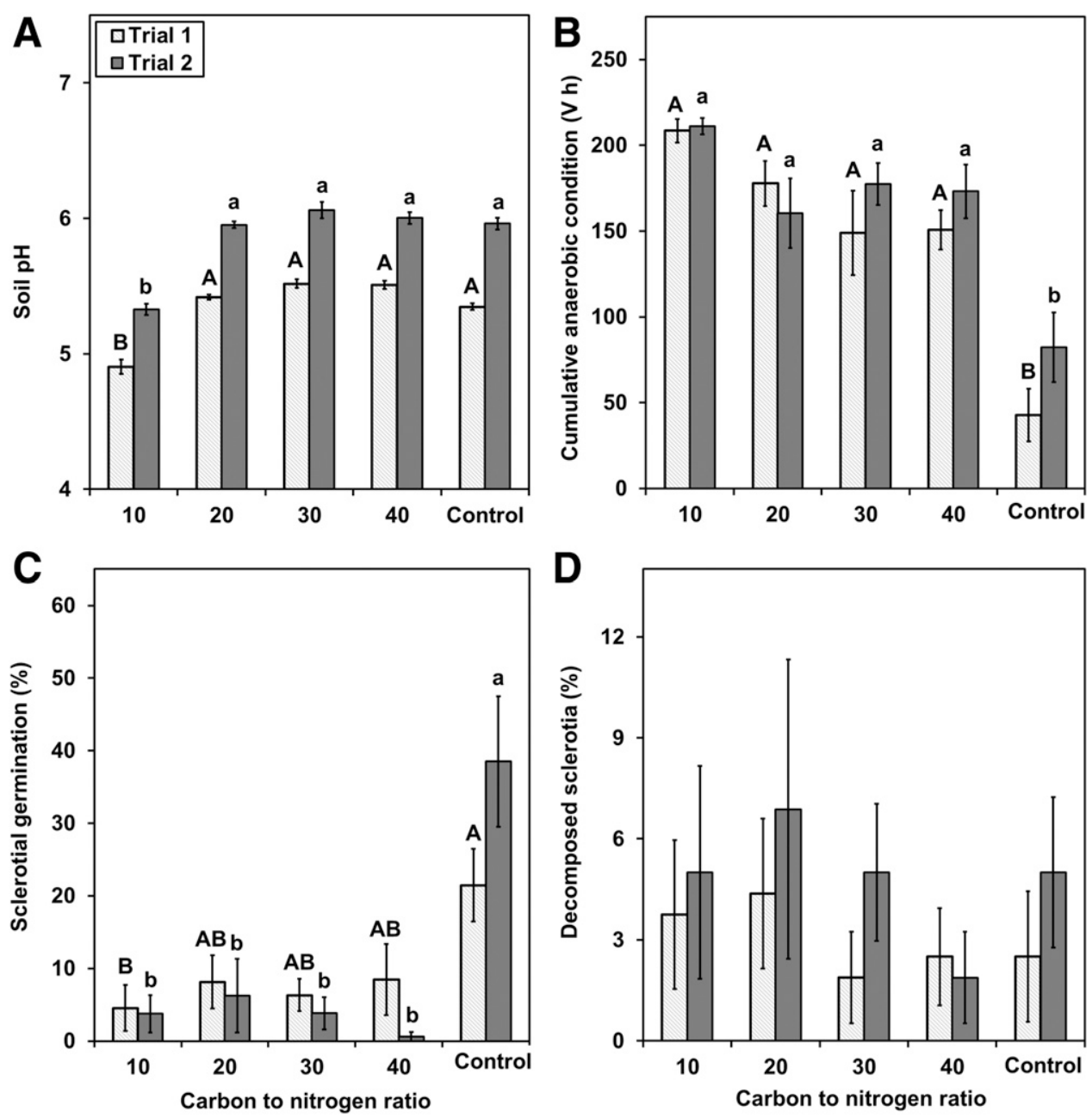








nonamended control. 
significant in trial $1(P<0.04)$, with higher $\mathrm{pH}$ for soil treated with dry molasses. Soil $\mathrm{pH}$ increased as ASD amendment $\mathrm{C}: \mathrm{N}$ ratio increased from 10:1 to 30:1 for dry molasses. Mean cumulative anaerobic conditions did not differ among ASD amendment type in either trial but values for ASD treatments were significantly higher than the nonamended control (Table 3, Fig. 1B). No interaction was observed between ASD amendment type and ASD amendment C:N ratio. Across both trials, the highest mean anaerobic condition values were recorded for ASD treatments with dry molasses amendment (191 V h), with an ASD amendment C:N ratio of 10:1 (210 V h) (data not shown).

TABLE 4. Effect of anaerobic soil disinfestation amendment on sclerotia of Sclerotium rolfsii in pot trials 1 and 2 (amendment and C:N ratio study)

\begin{tabular}{|c|c|c|c|c|c|c|}
\hline Trial, amendment ${ }^{\mathrm{z}}$ & $\begin{array}{c}\text { Sclerotial } \\
\text { germination } \\
(\%)\end{array}$ & $\begin{array}{c}\text { Trichoderma } \\
\text { colonization } \\
\text { of sclerotia } \\
(\%)\end{array}$ & $\begin{array}{c}\text { Fusarium } \\
\text { colonization } \\
\text { of sclerotia } \\
(\%)\end{array}$ & $\begin{array}{c}\text { Sclerotial } \\
\text { decomposition }(\%)\end{array}$ & $\begin{array}{c}\text { Colonization } \\
\text { by } \\
\text { unidentified } \\
\text { fungi }(\%)\end{array}$ & $\begin{array}{c}\text { Colonization } \\
\text { by fungi other } \\
\text { than } \\
\text { Trichoderma } \\
(\%)\end{array}$ \\
\hline \multicolumn{7}{|l|}{1} \\
\hline Control & $21.5 \pm 5.0 \mathrm{a}$ & $81.0 \pm 4.3 b$ & $2.5 \pm 1.4$ & $2.5 \pm 1.9$ & $1.9 \pm 1.0$ & $4.4 \pm 1.6$ \\
\hline Dry molasses based & $11.2 \pm 3.2 \mathrm{~b}$ & $91.8 \pm 2.6 \mathrm{a}$ & $0.7 \pm 0.5$ & $4.1 \pm 1.4$ & $4.5 \pm 1.4$ & $5.2 \pm 1.4$ \\
\hline Wheat bran based & $2.5 \pm 1.1 \mathrm{c}$ & $96.1 \pm 1.7 \mathrm{a}$ & $3.6 \pm 2.1$ & $2.2 \pm 1.2$ & $1.6 \pm 0.8$ & $5.2 \pm 2.4$ \\
\hline$P$ value & $<0.0001$ & 0.002 & 0.44 & 0.38 & 0.14 & 0.41 \\
\hline \multicolumn{7}{|l|}{2} \\
\hline Control & $38.5 \pm 9 \mathrm{a}$ & $54.2 \pm 9.2 \mathrm{~b}$ & $8.8 \pm 2.8$ & $5.0 \pm 2.2$ & $3.2 \pm 1.5$ & $12.0 \pm 3.2$ \\
\hline Dry molasses based & $3.8 \pm 1.5 \mathrm{~b}$ & $77.4 \pm 5.2 \mathrm{a}$ & $11 \pm 3.1$ & $5.3 \pm 2.3$ & $13.3 \pm 3.7$ & $24.2 \pm 5.2$ \\
\hline Wheat bran based & $3.4 \pm 2.6 b$ & $84.8 \pm 4.5 \mathrm{a}$ & $12.6 \pm 3.7$ & $4.1 \pm 1.8$ & $5.9 \pm 1.8$ & $18.5 \pm 4.4$ \\
\hline$P$ value & $<0.0001$ & 0.004 & 0.90 & 0.60 & 0.10 & 0.49 \\
\hline
\end{tabular}

y Values are least square means \pm standard error of four replicate pots. For each trial, within columns, values followed by different letters are significantly different according to Tukey's Test at $P<0.05$.

${ }^{\mathrm{z}}$ Control = covered, nonamended control.


Fig. 2. Effect of anaerobic soil disinfestation (ASD) amendment carbon to nitrogen (C:N) ratio on percentage sclerotial colonization by A, Trichoderma spp.; B, Fusarium spp.; C, unidentified fungi; and D, Fusarium spp. and other fungi after ASD treatment, pot study. Bars indicated by different letters are significantly different at $P<0.05$ according to Tukey's test. Capital letters are used to compare the respective means of trial 1 and small letters are used to compare respective means of trial 2. Error bars indicate standard error with four replicates; $10=\mathrm{C}: \mathrm{N}$ ratio 10:1, $20=\mathrm{C}: \mathrm{N}$ ratio 20:1, 30 $=\mathrm{C}: \mathrm{N}$ ratio $30: 1,40=\mathrm{C}: \mathrm{N}$ ratio $40: 1$, and Control = nonamended control. 
ASD treatment reduced sclerotial germination compared with nonamended controls in both trial 1 and trial $2(P<0.0001)$. In trial 1 , the lowest sclerotial germination was observed in the ASD treatments with wheat-bran-based amendment (Table 4). Sclerotial germination was lower in all ASD treatments (0.6 to 8.4\%) compared with the nonamended control (22 to $39 \%$ ), and this difference was significant with the 10:1 amendment $\mathrm{C}: \mathrm{N}$ ratio in trial 1 and all amendment $\mathrm{C}: \mathrm{N}$ ratios in trial 2 (Fig. 1C). However, sclerotial decomposition was not significantly affected by ASD amendment type, ASD amendment C:N ratio (Fig. 1D), or depth of burial. Both ASD amendment types had a significant positive impact on colonization of sclerotia by Trichoderma spp., with higher colonization in ASD treatments (93 to $95 \%$, trial 1 and 80 to $84 \%$, trial 2) compared with nonamended controls (81\%, trial 1 and 54\%, trial 2) (Fig. 2A). Colonization by other potential mycoparasites (Fusarium spp. and other unidentified fungi) was observed but was not different among ASD amendment types (Table 4) or ASD amendment C:N ratios (Fig. 2B, C, and D), except for unidentified fungi in trial 1 (Fig. 2C).

Sclerotial germination assessed for pathogen packets retrieved from burial depths of 5 and $15 \mathrm{~cm}$ was lower for ASD treatments compared with nonamended controls in trial 2, whereas sclerotial germination did not differ for the ASD treatments with dry molasses-based amendment and nonamended controls in trial 1 (Fig. 3A). At the 5-cm burial depth, sclerotial colonization by Trichoderma spp. was higher in ASD treatments (94 to $98 \%$ in trial 1 and 95 to $97 \%$ in trial 2) compared with nonamended controls (75\% in trial 1 and $64 \%$ in trial 2) but did not differ at the $15-\mathrm{cm}$ depth (Fig. 3B). Higher percentages of Fusarium spp. and other fungi were generally observed on sclerotia retrieved from the 15-cm depth (19 to 23\%) compared with the 5-cm depth $(2$ to $3 \%$ ) in ASD treatments in trial 2 but no differences were observed between ASD treatments and the nonamended controls (Fig. $3 \mathrm{C}$ and D).

ASD amendment rate effect on anaerobic conditions, and germination and colonization of sclerotia in pot trials 3 and 4. There was a significant but moderate negative correlation of sclerotial germination with anaerobic condition for both trials 3 and $4\left(r_{s}=-0.6\right.$ to $\left.-0.7, P<0.0001\right)$. Strong negative correlation $\left(r_{s}=-0.9, P<0.0001\right)$ was observed between sclerotial germination and Trichoderma colonization in trial 4 and moderate negative correlation observed in trial $2\left(r_{s}=-0.6\right.$ at $\left.P<0.005\right)$, indicating that lower sclerotial germination is associated with higher Trichoderma colonization. There was a negative, moderate correlation between percent sclerotial colonization with zygomycetes and sclerotial germination in both trials $\left(r_{s}=-0.5, P<0.05\right)$. There was no significant correlation of germination of sclerotia with colonization of sclerotia by Fusarium spp. and bacteria.

The data for the two depths of sclerotial burial were pooled because there was no effect of depth of sclerotial burial on sclerotial germination or colonization by Trichoderma spp. in trials 3 and 4. Average volumetric soil moisture in trial 3 was 0.27 to $0.28 \mathrm{~cm}^{3} / \mathrm{cm}^{3}$ and, in trial 4 , soil moisture was 0.23 to $0.27 \mathrm{~cm}^{3} / \mathrm{cm}^{3}$ in covered pots, with uncovered pots at 0.01 . Mean soil temperature did not differ among treatments during the treatment period, ranging from 21.3 to $26.2^{\circ} \mathrm{C}$ for trial 3 and 19.9 to $22^{\circ} \mathrm{C}$ for trial 4 . Average volumetric soil moisture content differed among treatments in both trials, ranging from 0.2 to $0.3 \mathrm{~cm}^{3} / \mathrm{cm}^{3}$. Soil $\mathrm{pH}$ was relatively higher in trial 4 than


Burial depth of sclerotial packets

Burial depth of sclerotial packets

Fig. 3. Effect of anaerobic soil disinfestation (ASD) amendments at depths of 15 and $5 \mathrm{~cm}$ on A, percentage sclerotial germination; percentage sclerotial colonization by B, Trichoderma spp.; C, Fusarium spp.; and D, unidentified fungi after ASD treatment, pot study. Bars indicated by different letters are significantly different at $P<$ 0.05 according to Tukey's test. Capital letters are used to compare the respective means of trial 1 and small letters are used to compare respective means of trial 2. Error bars indicate standard error with four replicates. Control $=$ nonamended control. 
trial 3 but no significant differences were observed among ASD amendment $\mathrm{C}$ rates for soil $\mathrm{pH}$ (Fig. 4A). Cumulative anaerobic conditions were not affected by ASD amendment rate differences from 2 to $8 \mathrm{mg} / \mathrm{g}$; however, anaerobic conditions were significantly higher in ASD treatments ( 141 to $158 \mathrm{~V}$ h in trial 3 and 107 to $150 \mathrm{~V}$ $\mathrm{h}$ in trial 4) than in the covered and uncovered nonamended controls (0 to $18 \mathrm{~V} \mathrm{~h}$ ) (Fig. 4B).

All ASD treatments were effective in suppressing sclerotial germination compared with the nonamended controls. In both trial 3 and 4, sclerotial germination was not significantly reduced by increasing ASD amendment rates of C above $2 \mathrm{mg} / \mathrm{g}$ of soil (Fig. 4C). However, germination with ASD amendment rate of $\mathrm{C}$ at $4 \mathrm{mg} / \mathrm{g}$ of soil may be more consistently low at this soil temperature given the narrower standard error. Sclerotial colonization by Trichoderma spp. was higher at all ASD amendment rates compared with nonamended controls in both trials 3 and 4 (Fig. 4D). Sclerotial colonization by Fusarium spp., zygomycetes, and bacteria was observed in all ASD treatments, with the highest percentage of colonization by all organisms observed for ASD amendment rates of C at 6 and $8 \mathrm{mg} / \mathrm{g}$ (Fig. 4E), indicating that, in addition to Trichoderma spp., colonization of sclerotia by other diverse microbes increased at higher ASD amendment $\mathrm{C}$ rates.

ASD amendment effect on anaerobic conditions, and sclerotial germination and colonization in field studies. In field trials, no significant correlations of sclerotial germination with soil moisture, soil pH, and microbial colonization were observed in 2013. However, there was a moderate negative relationship between Trichoderma colonization with IRIS tube paint removal $(P<0.04)$ and
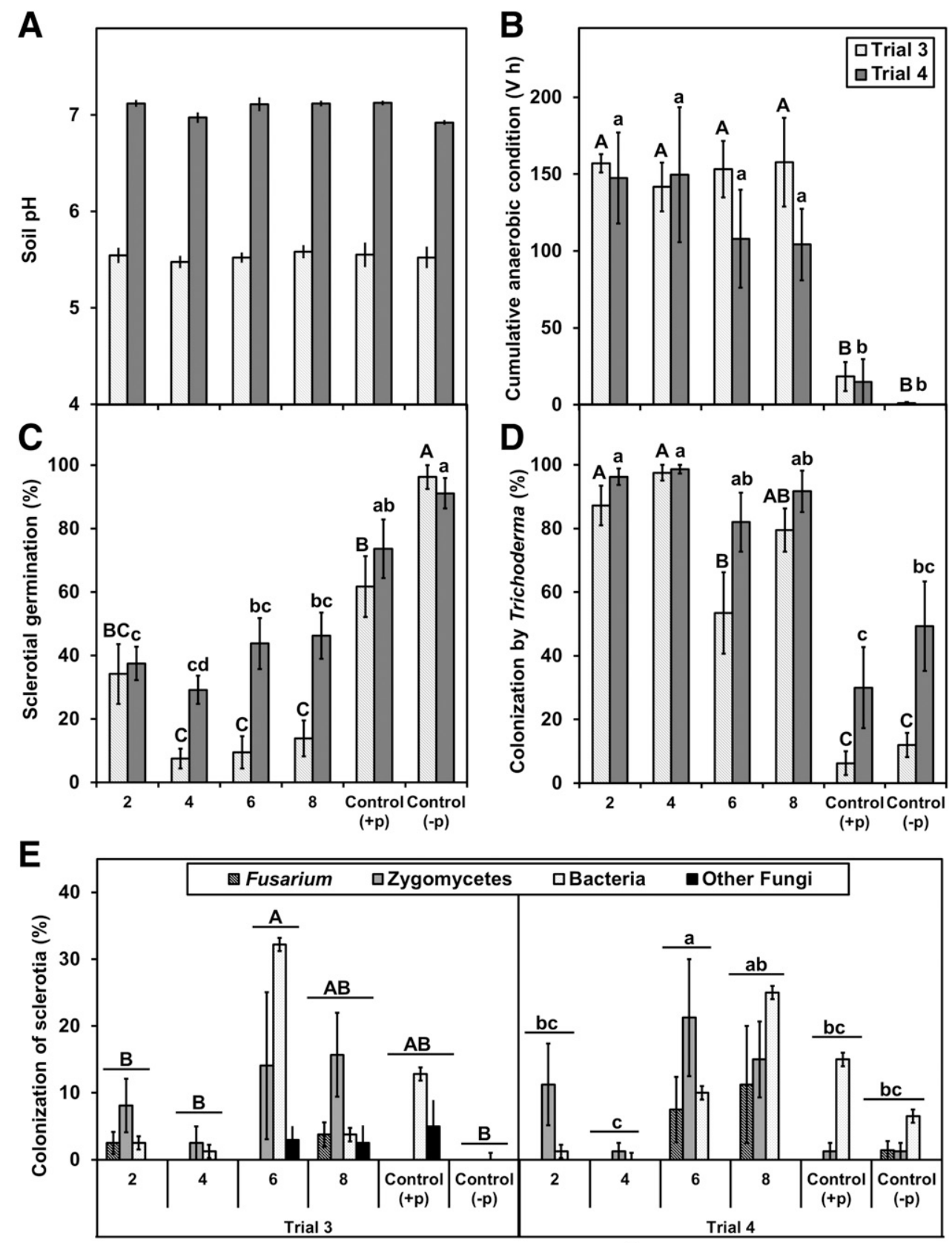

ASD C amendment rate ( $\mathrm{mg} \mathrm{C}^{-1}$ of soil)

Fig. 4. Effect of anaerobic soil disinfestation (ASD) amendment carbon (C) rates on $\mathbf{A}$, soil $\mathrm{pH}$; $\mathbf{B}$, cumulative anaerobic condition; $\mathbf{C}$, percentage sclerotial germination; and percentage sclerotial colonization by D, Trichoderma spp. and E, Fusarium spp., zygomycetes, bacteria and other fungi during ASD treatment, pot study. Bars with different letters are significantly different at $P<0.05$ according to Tukey's test. In E, different letters with a line above the error bars indicates significant differences for total sclerotial colonization by Fusarium spp., zygomycetes, bacteria, and other fungi. Capital letters are used to compare the respective means of trial 3 and small letters are used to compare respective means of trial 4. Error bars indicate standard error with four replicates. C amendment rates were 2, 4, 6 , and $8 \mathrm{mg} / \mathrm{g}$ of soil; Control $(+\mathrm{p})=$ polyethylene covered, nonamended control and Control $(-\mathrm{p})=$ uncovered, nonamended control. 
a positive relationship with soil moisture, initial soil $\mathrm{pH}$, other fungi, and Aspergillus colonization of sclerotia in $2013\left(r_{s}=0.4, P<0.04\right)$. In 2014, sclerotial germination had a moderate negative correlation with Trichoderma colonization of sclerotia $\left(r_{s}=-0.7, P<0.001\right)$. In addition, soil $\mathrm{pH}$ and IRIS tube paint removal were moderately correlated $\left(r_{s}=0.4, P<0.01\right)$.

Average soil temperatures did not differ among ASD treatments in either field study. In 2013, mean soil temperatures ranged from 22 to $25^{\circ} \mathrm{C}$ and, in 2014 , slightly higher mean soil temperatures were observed, with a range between 24 and $25^{\circ} \mathrm{C}$. Before treatment

TABLE 5. Effect of anaerobic soil disinfestation (ASD) amendment carbon/ nitrogen $(\mathrm{C}: \mathrm{N})$ ratio on soil gravimetric moisture content $(\mathrm{g} / \mathrm{g})$ in field trials ${ }^{\mathrm{y}}$

\begin{tabular}{llllll}
\hline & \multicolumn{2}{c}{ Field trial 1,2013} & & \multicolumn{2}{c}{ Field trial 2, 2014 } \\
\cline { 2 - 3 } \cline { 5 - 6 } Treatment $^{\mathrm{z}}$ & Pre ASD & Post ASD & & Pre ASD & Post ASD \\
\hline 10 & $2.5 \pm 0.16$ & $2.9 \pm 0.05 \mathrm{ab}$ & & $2.7 \pm 0.19$ & $3.4 \pm 0.24$ \\
20 & $2.6 \pm 0.09$ & $3.1 \pm 0.1 \mathrm{a}$ & & $2.9 \pm 0.11$ & $2.9 \pm 0.29$ \\
30 & $2.7 \pm 0.07$ & $2.8 \pm 0.15 \mathrm{~b}$ & & $3.1 \pm 0.26$ & $3.9 \pm 0.55$ \\
40 & $2.5 \pm 0.05$ & $2.5 \pm 0.17 \mathrm{~cd}$ & & $3 \pm 0.08$ & $2.9 \pm 0.35$ \\
LC30 & $2.7 \pm 0.1$ & $2.9 \pm 0.08 \mathrm{ab}$ & & $2.8 \pm 0.11$ & $3.1 \pm 0.31$ \\
Control & $2.5 \pm 0.05$ & $2.8 \pm 0.03 \mathrm{bc}$ & & $2.8 \pm 0.1$ & $3.2 \pm 0.29$ \\
\hline
\end{tabular}

y Within each column, values are least square means \pm standard error of four replicate plots. Values followed by different letters are significantly different according to Tukey's test at $P<0.05$.

$\mathrm{z}$ Treatments are $10=\mathrm{C}: \mathrm{N}$ ratio 10:1, 20 $=\mathrm{C}: \mathrm{N}$ ratio 20:1, 30 $=\mathrm{C}: \mathrm{N}$ ratio 30:1, $40=\mathrm{C}: \mathrm{N}$ ratio 40:1, LC30 (low carbon) $=\mathrm{C}: \mathrm{N}$ ratio $30: 1$ and $\mathrm{C}$ rate at $2 \mathrm{mg} / \mathrm{g}$ of soil, and Control = nonamended control. application, gravimetric soil moisture ranged from 2.5 to $2.7 \mathrm{~g} / \mathrm{g}$ in 2013 and was slightly higher in 2014 , ranging from 2.7 to $3.1 \mathrm{~g} / \mathrm{g}$ (Table 5). In 2013, after a 3-week treatment period, soil moisture content was significantly higher with an ASD amendment C:N ratio of 20:1 (C at 3.1 g/g of soil) when compared with C:N ratio of 30:1, 40:1, and the nonamended control ( $>2.8 \mathrm{~g} / \mathrm{g}$ of soil). There was no significant influence of ASD treatment on soil $\mathrm{pH}$ at pretreatment (5.8 to 6.0 during 2013 and 5.4 to 5.5 during 2014) and posttreatment (5.8 to 6.0 during 2013 and 5.9 to 6.1 during 2014) (data not shown). No decline in soil pH among treatments was observed from pretreatment to posttreatment in either field study, although soil $\mathrm{pH}$ was not monitored during treatment. Cumulative anaerobic conditions indicated by the IRIS tubes showed significantly enhanced anaerobic conditions in ASD treatments with C at $4 \mathrm{mg} / \mathrm{g}$ of soil $(P<0.05)$. The maximum iron solubilization by reduction (i.e., paint removal rates) in ASD-treated plots amended with $\mathrm{C}$ at $4 \mathrm{mg} / \mathrm{g}$ of soil, regardless of C:N ratio, were 31 to $42 \%$ in 2013 and 23 to $33 \%$ in 2014 . The lowest rates of iron solubilization were observed for the ASD treatment with an amendment rate of C at $2 \mathrm{mg} / \mathrm{g}$ of soil (6 to 28\%) and the nonamended control (1 to 16\%).

In 2013, sclerotial germination was relatively low among ASD treatments, ranging from $1 \%$ in amendment $\mathrm{C}: \mathrm{N}$ ratio $40: 1$ to $11 \%$ in $\mathrm{C}: \mathrm{N}$ ratios 10:1 and 20:1, compared with the nonamended control $(27 \%)$, although this difference was not significant $(P=0.06)$. However, in 2014, the germination of sclerotia was significantly lower in all ASD treatments ( 1 to $7 \%, P<0.0001)$ as compared with the nonamended control (31\%) (Fig. 5A). Relatively high sclerotial colonization by Trichoderma spp., Fusarium spp., zygomycetes,






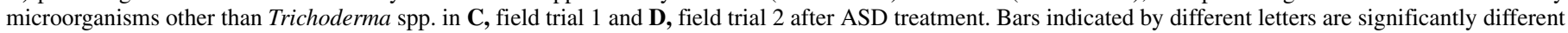


ratio 40:1, LC30 = C:N ratio 30:1 and C rate of $2 \mathrm{mg} / \mathrm{g}$ of soil ( $\mathrm{LC}=$ low carbon), and Control = nonamended control. 
and other fungi was observed (Fig. 5B, C, and D) but generally did not differ among treatments. Aspergillus colonization of sclerotia was observed in 2013 and bacterial colonization in 2014; however, the results were not significant in either study $(P=0.07$ for Trichoderma spp. and $P>0.1$ for all fungal colonization). The only significant colonization difference was observed for zygomycetes in $2014(P<0.02)$ (Fig. 5D), where the lowest parasitism was observed from the control and the highest from amendment $\mathrm{C}: \mathrm{N}$ ratios of 20:1 and 40:1.

\section{DISCUSSION}

Effectiveness for control of sclerotia was measured in terms of sclerotial germination and sclerotial colonization by various culturable soil microorganisms. The majority of sclerotia recovered from ASD treatments failed to germinate and were colonized by potential mycoparasites. The presence of endemic Trichoderma and Fusarium spp. and other fungi known to be mycoparasites of sclerotia (Coley-Smith and Cooke 1971; Elad et al. 1984; Hu et al. 2013; Rai and Saxena 1975) does suggest that sclerotia were either weakened or lysed during ASD treatment. At the same time, many sclerotia that germinated were also colonized by potential mycoparasites, suggesting that colonization alone does not explain ASD treatment effects on sclerotia germination. Sclerotial colonization by Trichoderma spp. was abundant in all studies; however, Aspergillus colonization was observed in field trial 1 (2013) and bacterial colonization in field trial 2 (2014). Trichoderma spp. are the most studied mycoparasites that are known to produce bioactive metabolites (Ownley et al. 2010) and produce enzymes such as $\beta-1,3-$ glucanase and chitinase as a means to degrade the protective outer layer of sclerotia (Elad et al. 1984) or reduce hyphal growth (Madi et al. 1997). It has been reported that eruptive germination of sclerotia in soil or weakening of the rind due to treatment effects can release nutrients that stimulate the colonization of sclerotia (Smith 1972). Colonization of sclerotia by zygomycetes (e.g., Rhizopus and Mucor spp.) was also observed. Zygomycetes are known to produce chitosan, a substance derived from chitin with antimicrobial activity (Gharieb et al. 2015). However, significant colonization of sclerotia by other mycoparasites as compared with the nonamended control was not observed in the present study. In addition, it is also expected that sclerotia are targeted by anaerobic bacteria during ASD treatment, especially Clostridia (Adandonon et al. 2015), during the highly anaerobic phase soon after amendment incorporation (Huang et al. 2015); however, the present study did not evaluate sclerotial decomposition by anaerobic bacteria.

With the application of amendments, regardless of amendment $\mathrm{C}: \mathrm{N}$ ratio and $\mathrm{C}$ rates, high cumulative anaerobic conditions were recorded within 3 weeks of ASD treatment, which was similar to previous studies (McCarty et al. 2014). Consistent relationships among anaerobic conditions, sclerotial germination, and Trichoderma colonization of sclerotia were observed only in the pot studies with varying $\mathrm{C}$ rates. Endemic Trichoderma spp. also colonized a higher number of sclerotia in ASD treatments compared with the nonamended control. However, under field conditions, sclerotial colonization by Trichoderma spp. was lower than in pot studies and not significantly different between ASD treatments and the nonamended control. Greater diversity in populations of microorganisms present in field soil and less available nutrients could lead to more competition for sclerotial colonization or parasitism. In addition, no significant differences among ASD amendment $\mathrm{C}: \mathrm{N}$ ratios in sclerotial germination or colonization by Trichoderma spp. were observed in either pot or field conditions, although Trichoderma populations are reported to increase in soils amended to obtain high $\mathrm{C}: \mathrm{N}$ ratios (e.g., 40:1) (Shaban et al. 1998). Overall, ASD was effective in reducing sclerotial germination compared with controls.

An ASD amendment rate of $\mathrm{C}$ at $4 \mathrm{mg} / \mathrm{g}$ of soil was optimal to suppress sclerotial germination due to more consistent suppression of sclerotial germination under the environmental conditions of this study. However, given no statistical differences observed in sclerotial germination between amendment rates of $\mathrm{C}$ at 2 and $4 \mathrm{mg} / \mathrm{g}$ of soil (at $\mathrm{C}: \mathrm{N}$ ratio of 30:1), it may be possible to use rates lower than $4 \mathrm{mg} / \mathrm{g}$ of soil to reduce amendment costs. Likewise, using rates of $\mathrm{C}$ at 2 or $4 \mathrm{mg} / \mathrm{g}$ of soil with ASD treatment resulted in the highest sclerotial colonization by Trichoderma spp. (Fig. 4D). Studies have suggested that increased depth of sclerotial burial increases mortality of sclerotia (Imolehin and Grogan 1980; Smith et al. 1989) because increased soil pressure increases sclerotial substrate leakage (Punja et al. 1984). However, in this study, there was no significant difference in mortality of sclerotia between two depths across ASD and control treatments. At the 15-cm depth for ASD treatments in trial 1, there was no difference in sclerotial mortality when compared with the nonamended control (Fig. 3A). In contrast, at $15 \mathrm{~cm}$, higher sclerotial mortality for ASD treatments than the nonamended control in trial 2 may be attributable to exposure to greater soil moisture (Abawi et al. 1985; Moore 1949) with lower soil $\mathrm{pH}$ and high soil anaerobic conditions (Table 3). Overall, ASD treatment using either dry molasses or wheat bran as $\mathrm{C}$ amendments was more effective than the nonamended control in inducing sclerotial mortality.

In short, ASD can effectively reduce percent sclerotial germination. With ASD treatments, the majority of sclerotia failed to germinate. For those that did germinate, there was a high rate of colonization, mainly by Trichoderma spp. This phenomenon was more prevalent at shallow $(5 \mathrm{~cm})$ than deep $(15 \mathrm{~cm})$ soil depths. However, no differences were observed among ASD amendment $\mathrm{C}: \mathrm{N}$ ratios for germination of sclerotia. The addition of dry molasses or wheat bran as organic amendments not only reduces pathogen inoculum but also likely contributes to increased populations of beneficial organisms that suppress $S$. rolfsii in the soil (Beute and Rodríguez-Kábana 1981). Moreover, organic matter enrichment, obtained with the addition of ASD amendments, improves soil physical, chemical, and biological properties (Bailey and Lazarovits 2003; Blum and Rodríguez-Kábana 2004; Bulluck et al. 2002) that can benefit crop production.

\section{ACKNOWLEDGMENTS}

We thank A. Saxton for statistical expertise and A. Wszelaki for her suggestions to improve the manuscript.

\section{LITERATURE CITED}

Abawi, G., Grogan, R., and Duniway, J. 1985. Effect of water potential on survival of sclerotia of Sclerotinia minor in two California soils. Phytopathology 75:217-221.

Adandonon, A., Momma, N., Hoshino, Y. T., and Makino, T. 2015. Bacterial populations concomitant with Sclerotium rolfsii sclerotia in flooded soil, as estimated by $16 \mathrm{~S}$ rRNA gene, PCR-DGGE and sequence analyses. J. Appl. Biosci. 93:8696-8712.

Akhtar, M., and Malik, A. 2000. Roles of organic soil amendments and soil organisms in the biological control of plant-parasitic nematodes: A review. Bioresour. Technol. 74:35-47.

Aycock, R. 1966. Stem rot and other diseases caused by Sclerotium rolfsii or the status of Rolfs' fungus after 70 years. N. Carolina Agric. Exp. Stn. Tech. Bull 174.

Bailey, K. L., and Lazarovits, G. 2003. Suppressing soil-borne diseases with residue management and organic amendments. Soil Tillage Res. 72: 169-180.

Belova, A., Narayan, T., and Olkin, I. 2013. Methyl bromide alternatives for strawberry and tomato pre-plant uses: A meta-analysis. Crop Prot. 54:1-14.

Beute, M., and Rodríguez-Kábana, R. 1981. Effects of soil moisture, temperature, and field environment on survival of Sclerotium rolfsii in Alabama and North Carolina. Phytopathology 71:1293-1296.

Blok, W. J., Lamers, J. G., Termorshuizen, A. J., and Bollen, G. J. 2000. Control of soilborne plant pathogens by incorporating fresh organic amendments followed by tarping. Phytopathology 90:253-259.

Blum, L. E., and Rodríguez-Kábana, R. 2004. Effect of organic amendments on sclerotial germination, mycelial growth, and Sclerotium rolfsii-induced diseases. Fitopatol. Bras. 29:66-74.

Bonanomi, G., Antignani, V., Capodilupo, M., and Scala, F. 2010. Identifying the characteristics of organic soil amendments that suppress soilborne plant diseases. Soil Biol. Biochem. 42:136-144.

Bonanomi, G., Gaglione, S. A., Incerti, G., and Zoina, A. 2013. Biochemical quality of organic amendments affects soil fungistasis. Appl. Soil Ecol. 72:135-142. 
Bulluck, L. R., Brosius, M., Evanylo, G. K., and Ristaino, J. B. 2002. Organic and synthetic fertility amendments influence soil microbial, physical and chemical properties on organic and conventional farms. Appl. Soil Ecol. 19:147-160.

Butler, D. M., Kokalis-Burelle, N., Muramoto, J., Shennan, C., McCollum, T. G., and Rosskopf, E. N. 2012a. Impact of anaerobic soil disinfestation combined with soil solarization on plant-parasitic nematodes and introduced inoculum of soilborne plant pathogens in raised-bed vegetable production. Crop Prot. 39:33-40.

Butler, D. M., Rosskopf, E. N., Kokalis-Burelle, N., Albano, J. P., Muramoto, J., and Shennan, C. 2012b. Exploring warm-season cover crops as carbon sources for anaerobic soil disinfestation (ASD). Plant Soil 355:149-165.

Castenson, K. L., and Rabenhorst, M. C. 2006. Indicator of reduction in soil (IRIS): Evaluation of a new approach for assessing reduced conditions in soil. Soil Sci. Soc. Am. J. 70:1222-1226.

Coley-Smith, J., and Cooke, R. 1971. Survival and germination of fungal sclerotia. Annu. Rev. Phytopathol. 9:65-92.

Coley-Smith, J., Ghaffar, A., and Javed, Z. 1974. The effect of dry conditions on subsequent leakage and rotting of fungal sclerotia. Soil Biol. Biochem. 6:307-312.

Csinos, A. S., Webster, T. M., Sumner, D. R., Johnson, A. W., Dowler, C. C., and Seebold, K. W. 2002. Application and crop safety parameters for soil fumigants. Crop Prot. 21:973-982.

Elad, Y., Barak, R., and Chet, I. 1984. Parasitism of sclerotia of Sclerotium rolfsii by Trichoderma harzianum. Soil Biol. Biochem. 16:381-386.

Fernandez, A. L., Sheaffer, C. C., Wyse, D. L., Staley, C., Gould, T. J., and Sadowsky, M. J. 2016. Structure of bacterial communities in soil following cover crop and organic fertilizer incorporation. Appl. Microbiol. Biotechnol. 100:9331-9341.

Gharieb, M. M., El-Sabbagh, S. M., Shalaby, M. A., and Darwesh, O. M. 2015. Production of chitosan from different species of zygomycetes and its antimicrobial activity. Int. J. Sci. Eng. Res. 6:123-130.

Goud, J.-K. C., Termorshuizen, A. J., Blok, W. J., and van Bruggen, A. H. C. 2004. Long-term effect of biological soil disinfestation on Verticillium wilt. Plant Dis. 88:688-694.

Hessen, D. O., and Anderson, T. R. 2008. Excess carbon in aquatic organisms and ecosystems: Physiological, ecological, and evolutionary implications. Limnol. Oceanogr. 53:1685-1696.

Hewavitharana, S. S., and Mazzola, M. 2013. Carbon source-dependent efficacy of anaerobic soil disinfestation (ASD) in suppression of Rhizoctonia root rot of apple. (Abstr.) Phytopathology 103:S2.60.

Hewavitharana, S. S., Ruddell, D., and Mazzola, M. 2014. Carbon sourcedependent antifungal and nematicidal volatiles derived during anaerobic soil disinfestation. Eur. J. Plant Pathol. 140:39-52.

Hu, X., Webster, G., Xie, L., Yu, C., Li, Y., and Liao, X. 2013. A new mycoparasite, Aspergillus sp. ASP-4, parasitizes the sclerotia of Sclerotinia sclerotiorum. Crop Prot. 54:15-22.

Huang, X., Wen, T., Zhang, J., Meng, L., Zhu, T., and Cai, Z. 2015. Toxic organic acids produced in biological soil disinfestation mainly caused the suppression of Fusarium oxysporum f. sp. cubense. BioControl 60:113-124.

Imolehin, E., and Grogan, R. 1980. Factors affecting survival of sclerotia, and effects of inoculum density, relative position, and distance of sclerotia from the host on infection of lettuce by Sclerotinia minor. Phytopathology 70:1162-1167.

Kissel, D. E., Sonon, L., Vendrell, P. F., and Isaac, R. A. 2009. Salt concentration and measurement of soil pH. Commun. Soil Sci. Plant Anal. 40:179-187.

Leite, M. F. A., Pan, Y., Bloem, J., Berge, H. T., and Kuramae, E. E. 2017. Organic nitrogen rearranges both structure and activity of the soil-borne microbial seedbank. Sci. Rep. 7: Article 42634.

Linderman, R., and Gilbert, R. 1973. Behavior of sclerotia of Sclerotium rolfsii produced in soil or in culture regarding germination stimulation by volatiles, fungistasis, and sodium hypochlorite treatment. Phytopathology 63:500-504.

Madi, L., Katan, T., Katan, J., and Henis, Y. 1997. Biological control of Sclerotium rolfsii and Verticillium dahliae by Talaromyces flavus is mediated by different mechanisms. Phytopathology 87:1054-1060.

Martin, F. 2003. Development of alternative strategies for management of soilborne pathogens currently controlled with methyl bromide. Annu. Rev. Phytopathol. 41:325-350.

McCarty, D. G. 2012. Anaerobic soil disinfestation: Evaluation of anaerobic soil disinfestation (ASD) for warm-season vegetable production in Tennessee. M.S. thesis, University of Tennessee, Knoxville.

McCarty, D. G., Inwood, S. E. E., Ownley, B. H., Sams, C. E., Wszelaki, A. L., and Butler, D. M. 2014. Field evaluation of carbon sources for anaerobic soil disinfestation in tomato and bell pepper production in Tennessee. HortScience 49:272-280.

Momma, N., Yamamoto, K., Simandi, P., and Shishido, M. 2006. Role of organic acids in the mechanisms of biological soil disinfestation (BSD). J. Gen. Plant Pathol. 72:247-252.
Moore, W. 1949. Flooding as a means of destroying the sclerotia of Sclerotinia sclerotiorum. Phytopathology 39:920-927.

Ownley, B. H., Gwinn, K. D., and Vega, F. E. 2010. Endophytic fungal entomopathogens with activity against plant pathogens: Ecology and evolution. BioControl 55:113-128.

Punja, Z. K. 1985. The biology, ecology, and control of Sclerotium rolfsii. Annu. Rev. Phytopathol. 23:97-127.

Punja, Z. K., Jenkins, S. F., and Grogan, R. G. 1984. Effect of volatile compounds, nutrients, and source of sclerotia on eruptive sclerotial germination of Sclerotium rolfsii. Phytopathology 74:1290-1295.

Rabenhorst, M. 2012. Simple and reliable approach for quantifying IRIS tube data. Soil Sci. Soc. Am. J. 76:307-308

Rai, J., and Saxena, V. 1975. Sclerotial mycoflora and its role in natural biological control of 'white-rot' disease. Plant Soil 43:509-513.

Reardon, C. L., and Wuest, S. B. 2016. Soil amendments yield persisting effects on the microbial communities-a 7-year study. Appl. Soil Ecol. 101:107-116.

Rodríguez-Kábana, R., Morgan-Jones, G., and Chet, I. 1987. Biological control of nematodes: Soil amendments and microbial antagonists. Plant Soil 100:237-247.

Rosskopf, E. N., Burelle, N., Hong, J., Butler, D. M., Noling, J. W., He, Z., Booker, B., and Sances, F. 2014. Comparison of anaerobic soil disinfestation and drip-applied organic acids for raised-bed specialty crop production in Florida. Acta Hortic. 1044:221-228.

Rosskopf, E. N., Kokalis-Burelle, N., Butler, D., Muramoto, J., and Shennan, C. 2010. Development of anaerobic soil disinfestation for Florida vegetable and flower production. Abstr. 84 in: Annu. Int. Res. Conf. Methyl Bromide Alternatives and Emissions Reductions, Orlando, FL.

Rosskopf, E. N., Serrano-Pérez, P., Hong, J., Shrestha, U., Rodríguez-Molina, M. C., Martin, K., Kokalis-Burelle, N., Shennan, C., Muramoto, J., and Butler, D. M. 2015. Anaerobic soil disinfestation and soilborne pest management. Pages 277-305 in: Organic Amendments and Soil Suppressiveness in Plant Disease Management, Vol. 46. K. M. Meghvansi and A. Varma, eds. Springer International Publishing, Cham, Switzerland.

Shaban, G., Fadl-Allah, E., and Yaser, M. 1998. Effect of C:N ratio on numbers and types of fungi in Egyptian soil. Egypt. J. Microbiol. 33:339-352.

Shennan, C., Muramoto, J., Bolda, M., Koike, S. T., Daugovish, O., Rosskopf, E., Kokalis-Burelle, N., and Klonsky, K. 2007. Optimizing anaerobic soil disinfestation: An alternative to soil fumigation? Pages 40-41 in: Annu. Int. Res. Conf. Methyl Bromide Alternatives and Emissions Reductions, San Diego, CA.

Shennan, C., Muramoto, J., Lamers, J., Mazzola, M., Rosskopf, E. N., Kokalis-Burelle, N., Momma, N., Butler, D. M., and Kobara, Y. 2014. Anaerobic soil disinfestation for soil borne disease control in strawberry and vegetable systems: Current knowledge and future directions. Acta Hortic. 1044:165-175.

Shrestha, U., Augé, R. M., and Butler, D. M. 2016. A meta-analysis of impact of anaerobic soil disinfestation on pest suppression and yield of horticultural crops. Front. Plant Sci. 7:1254.

Sinsabaugh, R. L., Manzoni, S., Moorhead, D. L., and Richter, A. 2013. Carbon use efficiency of microbial communities: Stoichiometry, methodology and modelling. Ecol. Lett. 16:930-939.

Smith, A. 1972. Nutrient leakage promotes biological control of dried sclerotia of Sclerotium rolfsii Sacc. Soil Biol. Biochem. 4:125-129.

Smith, V., Jenkins, S., Punja, Z., and Benson, D. M. 1989. Survival of sclerotia of Sclerotium rolfsii: Influence of sclerotial treatment and depth of burial. Soil Biol. Biochem. 21:627-632.

Spohn, M. 2015. Microbial respiration per unit microbial biomass depends on litter layer carbon-to-nitrogen ratio. Biogeosciences 12:817-823.

Strauss, S., and Kluepfel, D. 2015. Anaerobic soil disinfestation: A chemicalindependent approach to pre-plant control of plant pathogens. J. Integr. Agric. 14:2309-2318.

Streekstra, H., de Mattos, M. T., Neijssel, O., and Tempest, D. 1987. Overflow metabolism during anaerobic growth of Klebsiella aerogenes NCTC 418 on glycerol and dihydroxyacetone in chemostat culture. Arch. Microbiol. 147: 268-275.

Tao, R., Liang, Y. C., Wakelin, S. A., and Chu, G. X. 2015. Supplementing chemical fertilizer with an organic component increases soil biological function and quality. Appl. Soil Ecol. 96:42-51.

Thaning, C., and Gerhardson, B. 2001. Reduced sclerotial soil-longevity by whole-crop amendment and plastic covering. J. Plant Dis. Prot. 108:143-151.

Thomas, T. D., Ellwood, D. C., and Longyear, V. M. C. 1979. Change from homo-to heterolactic fermentation by Streptococcus lactis resulting from glucose limitation in anaerobic chemostat cultures. J. Bacteriol. 138:109-117.

Xu, Z., Gleason, M. L., and Mueller, D. S. 2009. Development of rapid method using oxalic acid to assess resistance among host cultivars to petiole rot caused by Sclerotium rolfsii var. delphinii. Online publication. Plant Health Prog. doi.org/10.1094/PHP-2009-0128-01-RS 